\title{
Tree barks characterization envisioning an integrated use in a biorefinery
}

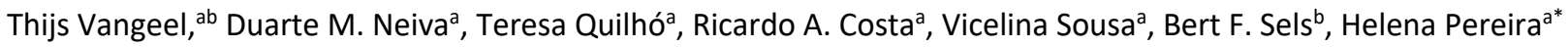 \\ ${ }^{a}$ Centro de Estudos Florestais, Instituto Superior de Agronomia, Universidade de Lisboa, Tapada da Ajuda, $1349-017$ Lisboa, \\ Portugal \\ ${ }^{\mathrm{b}}$ Center for Sustainable Catalysis and Engineering, KU Leuven, Belgium \\ *E-mail: hpereira@isa.ulisboa.pt
}

Keywords: bark, chemical composition, anatomy, lignin, extractives, biorefinery

\begin{abstract}
Tree barks are considerable waste streams in forest industries, and a potentially interesting resource for biorefineries. Barks of six relevant tree species, namely poplar (Populus $\times$ canadensis), black locust (Robinia pseudoacacia), red oak (Quercus rubra), willow (Salix sp.), Corsican pine (Pinus nigra subsp. laricio) and larch (Larix decidua) were anatomically and chemically characterized. Anatomical analysis illustrated the structural heterogeneity of the different barks with occurrence of various cell types and their arrangement in phloem, periderm and rhytidome. Summative chemical analysis showed a high extractives content (14-30 wt\%) for all barks. Black locust bark presented a substantial suberin content (10 wt\%). The lignin content was similar for most barks (22-29 wt\%), except for Corsican pine bark (45 wt\%). Analytical pyrolysis demonstrated that softwood bark lignin was mostly $\mathrm{G}$ type with a small amount of $\mathrm{H}$ units, whereas for hardwood species $\mathrm{S}, \mathrm{G}$ and $\mathrm{H}$ units were present, with low $\mathrm{S} / \mathrm{G}$ ratios (0.3-0.7). The cell wall structural polysaccharides were rather low. Total monosaccharides ranged from 35 to $44 \mathrm{wt} \%$, with glucose being predominant for almost all barks, followed by xylose in hardwood and mannose in softwood barks. Identification of the lipophilic extractives highlighted the predominance of resin acids for softwood barks, and fatty acids and triterpenoids for all barks. Analysis of the polar bark extracts revealed large variations in the content of phenolics (265-579 mg gallic acid equivalent/g extract), flavonoids (177-391 mg catechin equivalent/g extract) and condensed tannins (88-670 mg catechin equivalent/g extract). Furthermore, the polar extracts presented a high antioxidant potential (500-1209 mg trolox equivalent/g extract), as determined by the FRAP assay. Additionally, a very strong antioxidant activity (AAI > 2), as evaluated by the DPPH assay, was observed for all barks. In summary, the results highlight the marked anatomical and chemical interspecies variability in barks, thus suggesting the need for tailored biorefining approaches.
\end{abstract}

\section{Introduction}

Given plant based biomass is generally viewed as resource for a more sustainable bio-economy, biorefinery concepts to unravel such lignocellulosic biomass receive considerable attention.[1-5] In a biorefinery, biomass is processed into various product streams, suitable for downstream conversion into fuels, chemicals and materials, while minimizing wastes and adopting a full resource use approach.[1, 6, 7]

A major factor affecting the sustainability and economic viability of a biorefinery is the type and characteristics of the biomass feedstock. Instead of dedicated crops like corn or sugarcane, the use of agricultural wastes or forest residues greatly improves the overall sustainability of the biorefinery. [8] Tree barks are a nice example of such forest residues. Bark comprises 13-21 wt\% of a tree log on a dry-weight basis.[9] Prior to processing in wood industries, trees and logs are debarked, leaving vast amounts of bark as a low-value residue, which is mainly burned for energy recuperation or used as soil coverage in horticulture.[9-11] As such, tree barks combine abundance, availability and 
low cost with intrinsically rich chemical, physical and bioactive characteristics, thus making them a compelling feedstock for higher valued purposes such as chemicals and materials in a biorefinery.

A pre-requisite of any biorefinery process is a profound knowledge of the anatomical, physical and chemical characteristics of its raw material. Anatomically, bark is defined as all the tissues outside the vascular cambium and it is formed by the activity of two meristems: the vascular cambium and phellogen.[12] It includes a secondary phloem comprising the conducting and non-conducting phloem, and a rhytidome, that encloses the inner and sequential periderms (with phelloderm, phellogen and phellem) interspersed with layers of dead phloem tissue.[13] Chemically, bark consists of carbohydrate polymers (cellulose, hemicelluloses and pectins), phenolic polymers (lignin and condensed tannins), polyesters of fatty acids and glycerol (suberin), extractives (e.g. fatty acids, terpenoids, tannins) and inorganics.[14, 15] Compared to wood, barks tend to have higher inorganics and, often ill-defined, extractives content. Adding to the complexity, the chemical composition of bark varies widely between different tree species or even within the same species (e.g. depending on tree age or location in the tree).[14] This variability may be looked upon as a negative aspect, especially regarding a steady and unchangeable feedstock stream for an industry, but it may also be seen as a virtually unlimited source of different compounds yielding a wider range of potential bio-based products.

A biorefinery strives for full utilization of the biomass components. In recent years, lignocellulose-based biorefineries received considerable attention both regarding the isolation and use of the (hemi)cellulosic [5, 16-19] and lignin [2025] fractions. In bark specifically, the lignin and (hemi)cellulose fractions have been targeted in several strategies such as organosolv fractionation [26-28], hydrothermal or dilute acid pretreatment followed by enzymatic cellulose hydrolysis [29-31] and reductive catalytic fractionation [32-34]. In addition to lignin and (hemi)celluloses, barks can also contain another structural component, i.e. suberin, in their periderm. Suberin is a macromolecule of ester bonded fatty acids and glycerol and the main cell wall component of the phellem cells (also called cork cells).[35] In species with a well-developed phellem i.e. cork rich barks, the suberin content may be high and constitutes an interesting chemical resource.[36] Several species have been studied regarding their cork characteristics in view of a potential biorefinery integration, e.g. Quercus cerris [37], Pseudotsuga menziesii [38], Betula pendula [39], Plathymenia reticulata. [40], among others. Depolymerized suberin fragments constitute interesting building blocks for novel polyesters[41] or can be hydrodeoxygenated into biofuels[33, 42].

Apart from these structural components, barks contain a substantial amount of extractives (almost always higher than the respective wood).[43] In some cases, these extractives even constitute the largest fraction of the bark (e.g. $46 \mathrm{wt} \%$ for Acacia dealbata[44] and 56 wt\% Eucalyptus sideroxylon[45]). This non-structural fraction contains secondary plant metabolites that protect the plant from various biological stresses (e.g. insects, pathogens)[46] and may therefore be an interesting source of bioactive and antioxidant components.[47-50] Furthermore, alluring material applications such as adhesives, foams and epoxy resins, have been demonstrated for the condensed tannin fraction found in bark extracts.[51-53]

Many species such as spruce, fir, pines, larch, douglas fir, oak, beech, ash, poplar and eucalyptus are exploited on a large scale for their wood, thus producing considerable amounts of bark. In Europe, an estimated 20 million $\mathrm{m}^{3}$ bark is produced annually.[54] While a few of those barks have received some attention, many are still lacking the extensive knowledge required to improve their use for higher valued purposes than energy production through direct burning.

This contribution studies the barks of six different species with regard to their anatomical and chemical composition. Poplar (Populus $\times$ canadensis) [55], black locust (Robinia pseudoacacia) [56], red oak (Quercus rubra)[57], willow (Salix sp.)[55], Corsican pine (Pinus nigra subsp. laricio)[58] and larch (Larix decidua)[59] were selected as they are all very relevant tree species in Europe and their handling in wood-processing industries produces large amounts of the 
respective barks.[60, 61] Quercus rubra and Robinia pseudoacacia are native to North-America and considered invasive species in Europe, and are commercially exploited for their timber.[56, 57] Robinia pseudoacacia is especially valued for its highly durable wood, comparable to tropical hardwoods.[56, 62] Various poplar and willow species are fast-growing and are, next to timber, also considered for energy production.[55, 63] Corsican pine and larch are interesting conifer species for timber production. [58, 59] Pinus nigra is used for reforestation worldwide and the subspecies Corsican pine is valued for its straightness and high quality wood. $[58,64]$ Larix decidua is the only deciduous conifer species in Europe, and traditionally an important forestry species in alpine regions.[59]

For the bark of each of the aforementioned species, an anatomical characterization was carried out to gain insight in their structure and cellular features. Next, the summative chemical composition was determined for each bark, i.e. inorganics, extractives, (suberin,) lignin and holocellulose. Additionally, the carbohydrate composition of the polysaccharides fraction was ascertained. In order to gain more insight in the lignin composition of each bark, its $\mathrm{H} / \mathrm{G} / \mathrm{S}$ content was determined via fast pyrolysis coupled to GC/MS. Furthermore, the apolar bark extracts were identified by GC/MS after derivatization. The polar, ethanol/water extracts were analyzed with respect to their composition and reactivity. Their total phenolic, flavonoid and condensed tannin content were determined and their antioxidant properties were investigated.

\section{Materials and methods}

\section{Sampling and fractionation}

Barks of six different species were manually collected: poplar (Populus $x$ canadensis), from around 50 year old trees, in Genk (Belgium), black locust (Robinia pseudoacacia), from around 20 year old trees, located in Heusden-Zolder (Belgium), provided by Biomassaplein, red oak (Quercus rubra), from around 60 year old trees, in Hasselt (Belgium), willow (Salix sp.), from around 30 year old trees, in Hasselt (Belgium), and Corsican pine (Pinus nigra subsp. laricio, and larch (Larix decidua), both located in Hamond-Achel (Belgium) and provided by the division 'Forest, Nature and Landscape' (KU Leuven). The remaining wood was manually removed from the bark samples. The samples were airdried for several weeks at room temperature. The bark samples were knife-milled with a Retsch SM 2000 mill to pass a $6 \times 6 \mathrm{~mm}$ screen, after which they were milled again to pass a $1 \times 1 \mathrm{~mm}$ screen. The $<1 \mathrm{~mm}$ fraction was sieved using various screen sizes, viz. $850 \mu \mathrm{m}, 450 \mu \mathrm{m}, 250 \mu \mathrm{m}$ and $180 \mu \mathrm{m}$, to gain insight in the particle size distribution for the different bark samples. The sieved fractions were combined and mixed again, and the entire bark fraction $<1$ $\mathrm{mm}$ was used for subsequent analysis.

\section{Anatomical Analysis}

The anatomical studies were conducted on the bark samples of Populus x canadensis, Robinia pseudoacacia, Quercus rubra, Salix sp., Pinus nigra subsp. laricio and Larix decidua. Bark samples were impregnated with DP1500 polyethylene glycol.[65] Transverse and longitudinal microscopic sections of approximately $17 \mu \mathrm{m}$ thickness were prepared with a Leica SM 2400 microtome. The sections were stained with a double staining of chrysoidine/astra blue (lignin stains yellow with crysoidine and cellulose stains blue by astra blue) and were mounted on Kaiser glycerin. After $24 \mathrm{~h}$ drying, the lamellas were submerged into xylene for 30 minutes, dehydrated on $96 \%$ and $100 \%$ alcohol and mounted on Eukitt. Sudan IV was used for detection of suberin (suberin stains brownish red with Sudan IV).

Individual specimens were also macerated in a 1:1 solution of $30 \% \mathrm{H}_{2} \mathrm{O}_{2}$ (hydrogen peroxide) and $\mathrm{CH}_{3} \mathrm{COOH}$ (glacial acetic acid) at $60^{\circ} \mathrm{C}$ for $48 \mathrm{~h}$ and stained with astra blue.

Light microscopic observations were made using Leica DM LA and photomicrographs were taken with a Nikon Microphot-FXA. 
Bark terminology followed Angyalossy et al.[13]

\section{Summative chemical analysis}

Chemical summative analysis included determination of ash, extractives soluble in increasingly polar solvents (dichloromethane, ethanol and water), suberin, Klason and acid soluble lignin, and holocellulose, as well as the monomeric composition of polysaccharides. The procedures were adapted from Neiva et al.[66] and Miranda et al. [67].

Ash content was determined by combusting approximately $1 \mathrm{~g}$ bark overnight at $525^{\circ} \mathrm{C}$ and weighing the residue, following TAPPI standard T211 om-93. Extractives were determined in extraction thimbles by successive extractions with dichloromethane (6h), ethanol (16h) and water (16h) in a Soxhlet apparatus. The thimbles were oven-dried after each extraction and the extractives were quantified gravimetrically.

Suberin content was determined only for poplar, black locust, willow and red oak bark samples. The suberin in extractive-free barks was depolymerized via alkaline methanolysis. A $1.5 \mathrm{~g}$ extractive-free sample of each bark was refluxed with $100 \mathrm{ml}$ of a $3 \%$ solution of $\mathrm{NaOCH}_{3}$ in methanol during $3 \mathrm{~h}$. The sample was filtrated and washed with methanol. The residue was refluxed with $100 \mathrm{ml}$ methanol for $15 \mathrm{~min}$ and filtrated again. The combined filtrates were acidified to $\mathrm{pH} 6$ with $2 \mathrm{M} \mathrm{H}_{2} \mathrm{SO}_{4}$ and evaporated to dryness. The residues were suspended in $50 \mathrm{ml}$ water and the methanolysis products were recovered with dichloromethane in three successive extractions, each with $50 \mathrm{ml}$ dichloromethane. The combined extracts were dried over anhydrous $\mathrm{Na}_{2} \mathrm{SO}_{4}$. The dichloromethane was evaporated and the residue, containing the nonpolar monomer units of suberin (e.g. the long chain lipids) was quantified gravimetrically, and expressed relative to the oven-dry bark.[67]

Acid insoluble lignin (Klason lignin) and soluble lignin were determined on extractive-free (and suberin-free) material. Klason lignin was determined through acid hydrolysis, according to TAPPI standard T222 om-88. Sulphuric acid $(72 \%, 3.0 \mathrm{ml})$ was added to $0.35 \mathrm{~g}$ of sample, at $30^{\circ} \mathrm{C}$ for $1 \mathrm{~h}$ with occasional stirring after which it was diluted to a concentration of $3 \mathrm{wt} \% \mathrm{H}_{2} \mathrm{SO}_{4}$ and further hydrolyzed for $1 \mathrm{~h}$ at $120{ }^{\circ} \mathrm{C}$. After filtration in a $\mathrm{G} 4 \mathrm{crucible}$, the residue was thoroughly washed with distilled water and oven dried. Klason lignin was determined as the mass of solid residue after correction for ash content (determined as described above). Soluble lignin was determined through UV spectrophotometry, measuring the absorbance of the hydrolysate, from the Klason lignin procedure, at $205 \mathrm{~nm}$, according to TAPPI standard UM250 om-83. Total lignin content was calculated as the sum of Klason and soluble lignins.

The hydrolysis liquor resulting from the Klason lignin procedure was used to determine the polysaccharide composition. The neutral monosaccharides, glucuronic acid and galacturonic acid were determined by separation through a Dionex ICS-3000 High Pressure Ion Chromatographer, using an Aminotrap plus Carbopac SA10 column $(4 \times 250 \mathrm{~mm})$; a gradient of $\mathrm{NaOH}+\mathrm{CH}_{3} \mathrm{COONa}$ with a $1 \mathrm{~mL} / \mathrm{min}$ flow at $25{ }^{\circ} \mathrm{C}$ was used was eluent. Acetic acid was determined in a Waters 600 and measured with a UV/Vis detector at $210 \mathrm{~nm}$, with a Biorad Aminex $87 \mathrm{H} \mathrm{HPX} \mathrm{(300x}$ $7.8 \mathrm{~mm}$ ) column; $10 \mathrm{mN} \mathrm{H} \mathrm{SO}_{4}$ with a $0.6 \mathrm{~mL} / \mathrm{min}$ flow at $30{ }^{\circ} \mathrm{C}$ was used as eluent.[68]

The holocellulose content was determined on the extractive-free (and suberin-free) samples using the sodium chlorite method, as described by Rowell et al.[14]

All the chemical analyses, except monosaccharide analysis via HPLC, were made in triplicate. Results are reported relative to the oven dry starting material.

\section{Lipophilic extracts composition}


Dichloromethane extracts were dried in aliquots under $\mathrm{N}_{2}$ and then dried in a vacuum oven over phosphorus pentoxide. Around $1 \mathrm{mg}$ of the extract was dissolved in pyridine $(120 \mu \mathrm{l})$ and trimethylsilylated with bis(trimethylsily)trifluoroacetamide $(80 \mu \mathrm{l})$ and oven heated at $60^{\circ} \mathrm{C}$ during $30 \mathrm{~min}$. Following the reaction time, the derivatized dichloromethane extracts were injected in an Agilent GC 7890A coupled to 5975C MSD 70 eV electron impact voltage and with a Zebron $5 \mathrm{HT}$ Inferno column ( $30 \mathrm{~m} \times 0.25 \mathrm{~mm}$ i.d. $\times 0.25 \mu \mathrm{m}$ film thickness). The oven heating program started at $100^{\circ} \mathrm{C}$ (held for $1 \mathrm{~min}$ ), raised to $150^{\circ} \mathrm{C}$ at a rate of $10^{\circ} \mathrm{C} / \mathrm{min}($ ramp 1$)$, then increased to $200{ }^{\circ} \mathrm{C}$ at $5{ }^{\circ} \mathrm{C} / \mathrm{min}\left(\right.$ ramp2), followed to $300^{\circ} \mathrm{C}$ at $4{ }^{\circ} \mathrm{C} / \mathrm{min}\left(\right.$ ramp 3), and lastly raised to $380^{\circ} \mathrm{C}$ at $10^{\circ} \mathrm{C} / \mathrm{min}$ and held for $5 \mathrm{~min}$ (ramp4). The temperature of the injector was kept at $280^{\circ} \mathrm{C}$ and the MS interface at $220^{\circ} \mathrm{C}$; helium was the carrier gas with a total flow of $1 \mathrm{~mL} / \mathrm{min}$. The identification of the compounds (as TMS derivatives) were based on literature mass spectra, Wiley 6, NIST libraries data, and own interpretation of mass spectrometric fragmentation patterns.

\section{Phenolic content and antioxidant activity of the bark extract}

The extraction procedure and phenolic content analysis was adapted from Miranda et al.[45] The ground bark was extracted in an ethanol/water solution $(50 / 50, \mathrm{v} / \mathrm{v})$ for $60 \mathrm{~min}$ at $50{ }^{\circ} \mathrm{C}$ using an ultrasonic bath. The insoluble material was removed by filtration and the extract was stored at $4{ }^{\circ} \mathrm{C}$. The solid residue was dried at $105^{\circ} \mathrm{C}$ and the extraction yield determined gravimetrically.

The phenolic content of the barks was determined as total phenols, flavonoids and tannins content. All the colorimetric assays were made in triplicate.

Total phenolics content was determined by the Folin-Ciocalteu method[69] using gallic acid as standard and expressed as milligrams of gallic acid equivalents (GAE)/g of dry bark or dry bark extract. Total flavonoids content was determined by an aluminium chloride colorimetric assay[70] and condensed tannins by the vanillin- $\mathrm{H}_{2} \mathrm{SO}_{4}$ method[71] using (+)-catechin as standard. The results were expressed as $\mathrm{mg}$ of catechin equivalents (CE)/g of dry bark or dry bark extract.

The analysis of antioxidant properties of the barks was determined by the DPPH method (free radical scavenging activity) and the FRAP method (ferric reducing antioxidant power).

The DPPH method was adapted from Miranda et al.[45] The antioxidant activity of the bark ethanol/water extract was determined using 2,2-diphenyl-1-picrylhydrazyl hydrate (DPPH) and expressed as (i) I $C_{50}$ (extract concentration required for $50 \%$ DPPH inhibition), (ii) antioxidant activity index (AAI = final DPPH concentration/ $/ \mathrm{C}_{50}$ ) [72] and (iii) as Trolox equivalents (TE) or gallic acid equivalents (GAE) antioxidant capacity.

The FRAP assay was adapted from Benzie and Strain[73] and the results were expressed as $\mathrm{mg}$ of Trolox equivalents (TE) or gallic acid equivalents (GAE)/g of dry bark or dry bark extract.

\section{Pyrolysis-GC/MS}

The pyrolysis-GC/MS procedure was adapted from Marques et al.[74] For this procedure, extractive-free bark was used to avoid interference of extractives with the lignin analysis. The extractive-free barks were milled to a fine powder using a vibratory ball mill (Retsch MM200 mixer), dried under vacuum over phosphorus pentoxide and then characterized by Py-GC/MS. Approximately 100-120 $\mu \mathrm{g}$ of each bark was weighed in a quartz boat and pyrolysed at $550^{\circ} \mathrm{C}$ for $1 \mathrm{~min}$ in a CDS Pyroprobe 5150 Pyrolyzer connected to an Agilent GC 7890B coupled to a mass detector system 5977B at $70 \mathrm{eV}$ electron impact voltage. The fused-silica capillary column used was a ZB-1701 $(60 \mathrm{~m} \times 0.25$ $\mathrm{mm}$ i.d. $\times 0.25 \mu \mathrm{m}$ film thickness). The oven heating program started at $40{ }^{\circ} \mathrm{C}$ (held for $4 \mathrm{~min}$ ), raised to $70{ }^{\circ} \mathrm{C}$ at a rate of $10^{\circ} \mathrm{C} / \mathrm{min}\left(\operatorname{ramp~1)}\right.$ ), then to $100^{\circ} \mathrm{C}$ at $5^{\circ} \mathrm{C} / \mathrm{min}\left(\right.$ ramp 2), raised to $265^{\circ} \mathrm{C}$ at $3^{\circ} \mathrm{C} / \mathrm{min}$ and held for $3 \mathrm{~min}(\mathrm{ramp}$ 3), and lastly to $270^{\circ} \mathrm{C}$ at $5^{\circ} \mathrm{C} / \mathrm{min}$ and held for $9 \mathrm{~min}\left(\right.$ ramp 4). The temperature of the injector was kept at $270{ }^{\circ} \mathrm{C}$ 
and the GC/MS interface at $280^{\circ} \mathrm{C}$; and helium was the carrier gas with a total flow of $1 \mathrm{~mL} / \mathrm{min}$. The compounds were identified using the Wiley-NIST libraries and literature.[75, 76] The $p$-hydroxyphenyl (H), guaiacyl (G) and syringyl (S) units (lignin derived products) were identified and their pyrogram peak area was used to calculate their molar percentage, relative to the other lignin derived compounds, according to the following formula:

$$
\text { Mol \% lignin }- \text { derived compound }=\frac{\text { Area compound } * \frac{1}{M W \text { compound }}}{\sum\left(\text { Area compound } * \frac{1}{M W \text { compound }}\right)} * 100
$$

These molar percentages of individual lignin compounds were used to calculate the molar percentage of $H, G$ and $S$ units, and the $S / G$ ratio.

\section{Results and discussion}

\section{Anatomy}

Figures S1-6 (Supplementary information) represent the bark structure of Pinus nigra subsp. laricio and Larix decidua (Gymnosperms) and Populus $x$ canadensis, Robinia pseudoacacia, Quercus rubra and Salix sp. (Angiosperms) analyzed under light microscope. Anatomical differences were noted in tissues and layers of the barks, showing their structural heterogeneity within genus and species, as described in literature.[77] The tissues and their distribution pattern are indicated in each figure; in general the anatomical features are according to literature for the genera/species as already described i.e. for Pinus nigra[78] and other Pinus sp.[79-81]; Larix decidua[78]; Populus tremula[82], P.alba and P.nigra[77]; Robinia pseudoacacia[13, 77, 78]; Quercus rubra[78] and other Quercus sp.[79, 83-86] and Salix sp.[77, 87].

The rhytidome varied in thickness, texture and morphology. In all the studied species, the rhytidome is of scale bark type, since the sequent periderms are formed as overlapping layers, each cutting out a scale of tissue.[12] The external appearance of the barks was flaky-scale bark in $P$. nigra, fissured in L. decidua, longitudinally furrowed with short deep furrows in Q. rubra, deeply furrowed into grooves in R. pseudoacacia and Populus, and deeply fissured in Salix sp. The observations of bark under the stereoscope can be found in the supplementary information (Figs. S1.1 A-B, Figs. S2.1 A-B; Figs. S3.1 A; Figs. S4.1 A; Figs. S5.1 A, Figs. S6.1 A). In the rhytidome, the number of periderms varied e.g. 9 periderms in Salix sp (Fig. S6.1 A1) and more than 10 in R. pseudoacacia. Phellem (cork) cells were observed in R. pseudoacacia (Fig. S4.1 B, C) and L. decidua (Fig. S2.1 C, D); especially R. pseudoacacia bark showed abundant phellem cells in each periderm. The barks of $P$. nigra subsp. laricio, Q. rubra and Salix sp. contained little or no cork. P. nigra subsp. laricio showed highly sclerified phellem cells (Fig. S1.1 C, E).

The conducting phloem, the mostly living tissue produced by the vascular cambium, includes the conducting cells, i.e. the sieve cells with Strasburger cells in Gymnosperms and sieve tube elements with companion cells in Angiosperms. These sieve cells were observed with different grouping and distribution within the phloem in $P$. nigra subsp. laricio (Figs. S1.1 E), in L. decidua (Figs. S2.1 E, G), in P. canadensis (Figs.S3.1 E, G), in R. pseudoacacia (Fig. S4.1 D), in Q. rubra (Fig. S5.2 C) and in Salix sp. (Fig. S6.1 C, E; Fig. S6.2 A). The conducting phloem also includes the axial parenchyma (storage tissue) and rays (storage/transversal conduction), both non-lignified and thin-walled, and the fibers (mechanical support) with lignified secondary cell walls. The occurrence and pattern of distribution of these tissues varied in the phloem of different genera, e.g. the axial parenchyma forms bands in R. pseudoacacia (Figs. S4.1 B); the fibers occur in tangential bands more or less regularly, alternating with bands containing the sieve tubes and axial parenchyma in R. pseudoacacia (Figs. S4.1 B), Salix sp. (Fig. S6.1C) or in tangential rows and grouped in and $P$. canadensis (Fig. S3.1 E, F). Fibers are thickened in R. pseudoacacia (Fig. S4.2 B) and are absent in P. nigra and $L$. decidua; the rays (storage/transversal conduction) varied from thin and uniseriate i.e. in P. nigra, L. decidua 
(Fig. S2.2 A) and in Salix sp. (Fig. S6.2 A), to multiseriate i.e. in Q. rubra (Fig. S5.2 B, C) and R. pseudoacacia. Radially waving rays appeared in L. decidua (Fig. S2.1 C, E).

In the non-conducting phloem, the conducting tissue collapsed and the structure became disorganized with distortion and expansion of cells, e.g. expanded parenchyma cells occurred in P. canadensis (Figs. S3.2 A, B); in some cases sclereids (scl) and fibrosclereids ( $\mathrm{fscl}$ ), which are thick and heavily lignified cells walls of mechanical support, also appeared i.e. in P. canadensis (Figs. S3.1C; 3.2 C) and in Q. rubra as abundant groups and clusters (Figs. S5.1 EG; S5.2 A, C) and in L. decidua (Figs. S2.1 E; S2.2 A, B) in form of isolated and round cells, when observed in transverse view.

Crystals, presumably of calcium oxalate and mostly present as prismatic crystals, were common in all the barks and found in sclereids (i.e. in Q. rubra, Figs. S5.2 A, E) and parenchyma cells (i.e. in Q. rubra Fig. S5.2B, in R. pseudoacacia Figs. S4.2 A, B, C or in Salix sp. Figs. S6.2 A, B, C, also occurring along the fibers groups); cubical crystals were found in L. decidua (Fig. 2.2 A); mineral inclusions were also observed in ray cells, i.e. in Salix sp. (Fig. S6.2 A).

Axial and radial resin ducts, provided with a distinct epithelium, appeared in P. nigra $x$ laricio (Fig. S1.1 F) and in $L$. decidua (Figs. S2.1 F; 2.2 A). Phenolic compounds were observed by dark color staining in axial and ray parenchyma cells of phloem and rhytidome (i.e. in P. nigra x laricio Figs. S1.2 C, in P. canadensis Fig. S3.1 F, in Q. rubra Fig. S5.1 C or in Salix sp. Figs. S6.1 B, D, S6.2 A) in the sclereids (i.e. in P. canadensis, Figs. S3.1 C) and in phellem (i.e. in P. nigra subsp. laricio Figs. S1.1 C, E and in Q. rubra Figs. S5.1 C, D).

\section{Chemical analysis}

A summative chemical composition was determined for the barks of the six different species using the entire $<1 \mathrm{~mm}$ fraction for analysis, to ensure that the complete bark was analyzed and therefore no bias through sieving could occur. [67] The granulometric distribution within this $<1 \mathrm{~mm}$ fraction is shown in Fig. S7 (Supplementary information), illustrating that willow bark produces a large share of fines upon milling ( $55 \mathrm{wt} \%<180 \mu \mathrm{m}$ ), while red oak bark milling results in predominantly coarser particles ( $41 \mathrm{wt} \%>425 \mu \mathrm{m})$.

The chemical summative analysis encompasses the determination of ash, extractives, suberin, lignin, and holocellulose. The results are shown in table 1. For comparison, some studies on the chemical composition of barks of these species (or genera) have already been conducted elsewhere: poplar (Populus tremuloides)[88], red oak[89, 90], black locust[89], larch (Larix leptolepis)[91], willow[92, 93], pine (Pinus sy/vestris)[67].

Table 1: Chemical composition and monomeric carbohydrate composition of six different barks. For all the analyses, the entire $<1$ $\mathrm{mm}$ fraction was used. For larch and Corsican pine, the suberin content was not determined (-). All values are expressed relative to the oven dry, raw material (wt\%).

\begin{tabular}{|c|c|c|c|c|c|c|}
\hline & Poplar & Red oak & Black locust & Willow & Corsican pine & Larch \\
\hline Ash & $3.24 \pm 0.21$ & $8.89 \pm 0.05$ & $7.27 \pm 0.02$ & $10.25 \pm 0.03$ & $1.68 \pm 0.03$ & $1.06 \pm 0.01$ \\
\hline Extractives & $21.78 \pm 0.37$ & $24.22 \pm 0.4$ & $16.27 \pm 0.63$ & $29.09 \pm 0.47$ & $13.91 \pm 0.42$ & $30.05 \pm 1.86$ \\
\hline Dichloromethane & $3.01 \pm 0.19$ & $7.43 \pm 0.44$ & $3.58 \pm 0.04$ & $3.29 \pm 0.58$ & $3.97 \pm 0.05$ & $2.76 \pm 0.04$ \\
\hline Ethanol & $13.73 \pm 0.3$ & $12.67 \pm 0.75$ & $7.18 \pm 0.34$ & $19.89 \pm 0.06$ & $5.45 \pm 0.31$ & $19.13 \pm 0.35$ \\
\hline Water & $5.05 \pm 0.47$ & $4.11 \pm 0.36$ & $5.50 \pm 0.30$ & $5.91 \pm 0.42$ & $4.49 \pm 0.65$ & $8.16 \pm 2.04$ \\
\hline Suberin & $3.03 \pm 0.08$ & $3.92 \pm 0.32$ & $10.34 \pm 0.86$ & $1.82 \pm 0.03$ & - & - \\
\hline Lignin & $28.98 \pm 0.15$ & $21.87 \pm 0.37$ & $23.36 \pm 0.10$ & $21.89 \pm 0.27$ & $45.07 \pm 1.18$ & $28.81 \pm 0.13$ \\
\hline Klason & $27.93 \pm 0.14$ & $19.33 \pm 0.17$ & $21.28 \pm 0.17$ & $20.09 \pm 0.22$ & $44.49 \pm 1.20$ & $28.38 \pm 0.11$ \\
\hline Acid soluble & $1.06 \pm 0.07$ & $2.54 \pm 0.24$ & $2.08 \pm 0.07$ & $1.8 \pm 0.07$ & $0.58 \pm 0.04$ & $0.43 \pm 0.03$ \\
\hline
\end{tabular}




\begin{tabular}{lcccccc} 
Holocellulose & $34.58 \pm 0.4$ & $44.45 \pm 0.55$ & $37.31 \pm 0.05$ & $37.4 \pm 0.67$ & $42.87 \pm 1.59$ & $41.96 \pm 1.13$ \\
Polysaccharides & & & & & & \\
Arabinose & 1.85 & 1.70 & 2.94 & 1.57 & 2.93 & 1.82 \\
Galactose & 1.05 & 0.81 & 1.11 & 1.17 & 1.97 & 1.45 \\
Glucose & 19.23 & 13.47 & 17.43 & 16.66 & 18.63 & 22.49 \\
Xylose & 8.09 & 14.08 & 4.86 & 5.05 & 3.54 & 3.32 \\
Mannose & 1.14 & 0.27 & 0.96 & 0.75 & 4.79 & 4.52 \\
Rhamnose & 0.38 & 0.28 & 0.42 & 0.33 & 0.23 & 0.21 \\
Galacturonic acid & 1.87 & 0.90 & 1.49 & 1.15 & 1.17 & 1.17 \\
Acetic acid & 0.14 & 0.21 & 0.10 & 0.11 & 0.61 & 0.41 \\
\hline
\end{tabular}

The ash content of the barks varied considerably between species. In some reports, the ash content is overestimated, due to contamination with extraneous material from the handling and debarking process. [68] However, since all the barks were obtained directly from the trees, it is acceptable to assume that these values correspond to the true content and are not distorted by any extraneous contaminants.

The softwood species larch and Corsican pine have the lowest ash content (1.1 and $1.7 \mathrm{wt} \%$ respectively), which corroborates earlier findings that softwood barks tend to have lower ash content when compared to hardwood barks.[90, 94] Very high ash contents were observed for black locust, red oak and willow barks (7-10 wt\%), whereas poplar bark displayed an intermediate ash content (3.2 wt\%). Barks are known to contain higher amounts of minerals than their respective woods, with some species presenting crystals (e.g. calcium oxalate) as a potential defense mechanism.[46, 95] Indeed, the high amount of ash in black locust, red oak and willow may be explained by the abundant presence of mineral crystals as observed by anatomical analysis, i.e. in red oak (Fig. S5.2 A, B, C, E), black locust (Fig. S4.2 A, B, C) and willow (Fig. S6.2A, B, C). The high ash content of these barks will make them poor raw materials for energy purposes by direct burning, or for production of pellets and briquettes.

The total content of extractives was determined via successive extractions with increasingly polar solvents, i.e. dichloromethane, ethanol and water. In most species, barks tend to be especially enriched in extractives when compared to their respective woods, making them interesting materials for extracting these fractions through simple processes and at mild conditions.[49]

The highest amount of extractives was found in larch and willow barks (30.1 and $29.1 \mathrm{wt} \%$ ) for which the ethanol extraction yielded roughly two-thirds of the total extractives. Black locust bark has the highest amount of apolar extractives (7.4 wt\%), i.e. extracted by dichloromethane, while in the other barks these dichloromethane extracts comprise roughly 2.5 - $4 \mathrm{wt} \%$. Corsican pine and black locust barks have the lowest total amount of extractives (13.9 and $16.3 \mathrm{wt} \%)$. For black locust and red oak barks, the total amount of extractives (16.3 and $24.2 \mathrm{wt} \%$ ) was higher than previously reported by Sillero et al. (12.7 and $12.1 \mathrm{wt} \%)$.[89] This illustrates the intra-species variations that can occur with different growing conditions or age.[14]

Suberin content was determined on the pre-extracted samples via alkaline methanolysis, followed by dichloromethane/water extraction to obtain the apolar compounds. The suberin content was highest for black locust $(10.3$ wt\%), which is in good agreement with earlier reports. $[32,89]$ Indeed, the anatomical analysis highlighted the large amount of phellem cells in the periderms of black locust (Fig. S4.1 B, C), thereby confirming the chemical results. Suberin content in barks is related to the proportion of cork in the periderms since only the phellem cells contain suberin.[35] In fact, the suberin content in cork tissue is particularly high e.g. $42.8 \mathrm{wt} \%$ in cork oak [96] and 36.2 wt\% in birch [39] corks. Poplar, red oak, and willow barks contain substantially less suberin (3.0, 3.9 and 1.8 $w t \%$, respectively) in accordance with the anatomical observations showing that these barks possess thin periderms with a small amount of phellem cells. The suberin content was not determined for Corsican pine and larch barks, as 
pines and larches contain a very small proportion of phellem and therefore little to no suberin.[67, 80, 91]. Our anatomical observations showed that the periderm of larch included 5 or more phellem cell layers in the periderm (Fig. S1.1 C, D) as recently highlighted.[97] Corsican pine bark showed a small number of phellem cells in the rhytidome, but they were thick-walled and sclerified (Fig. S1.1 C, E),

Lignin content was determined on the suberin-free (or extractive-free in case of Corsican pine and larch) samples via acid hydrolysis of the carbohydrates (Klason lignin) and with the acid soluble lignin analyzed via UV-Vis spectroscopy. The lignin content of most barks ranged from $21 \mathrm{wt} \%$ to $29 \mathrm{wt} \%$, with Corsican pine bark presenting an exceptionally high lignin content. The softwood barks presented a higher lignin content than most of the hardwood barks (with the exception of poplar bark) and lower acid soluble lignin content, which is in line with the observations for wood.[20,98] Corsican pine presented by far the highest lignin content (45.1 wt\%). However, this high lignin content should be interpreted with caution, as also non-lignin components could precipitate after acid hydrolysis, e.g. condensed tannins that were not removed during the successive soxhlet extractions, thereby resulting in a false high lignin content.[14] As mentioned before, Corsican pine bark showed the lowest amount of extractives (especially ethanol and water extractives), which might also point towards the presence of high molecular weight condensed tannins that were not extracted with ethanol or water in a soxhlet setup.

Holocellulose content was measured by delignification of the suberin-free (or extractive-free) samples with sodium chlorite. The holocellulose content ranged from 35 to $45 \mathrm{wt} \%$, with red oak bark having the highest holocellulose content (44.5 wt\%).

The monosaccharides were quantified by liquid chromatography of the hydrolysis liquor resulting from the Klason procedure. The monomeric composition of polysaccharides, viz. neutral sugars, uronic acids and acetates, is shown in table 1. Larch bark has the highest glucose content ( $22.5 \mathrm{wt} \%)$, indicating a higher cellulose content. Red oak bark, on the other hand, has the lowest glucose content (13.5 wt\%) but also the highest content of non-glucose carbohydrates, indicating a higher hemicellulose content. The hardwood barks have the highest xylose content (highest in red oak, $14.1 \mathrm{wt} \%$ ), in agreement with glucuronoxylan being the major hardwood hemicellulose type.[14] The softwood barks, larch and Corsican pine, contain a substantial amount of mannose ( 4.5 and 4.8 wt\%), in contrast to the hardwood barks $(<1.1 \mathrm{wt} \%)$, in line with the hemicellulose composition of softwoods containing mainly galactoglucomannan.[14] The lack of significant galacturonic acid indicates low pectin content of for all barks.[14]

Comparing the polysaccharides content, i.e. determined by summing up the monosaccharides, with the holocellulose content, i.e. determined by delignification, shows a consistently higher value for the holocellulose content. This is due to incomplete delignification for barks during the sodium chlorite procedure used for holocellulose determination, therefore making the polysaccharide quantification through monosaccharides determination the most viable and correct one.[9] As chemical compositional analyses have been tailored for wood, they are sometimes less adequate to describe non-wood lignocellulosic materials such as barks.

\section{Lignin composition}

The lignin composition of the different bark samples was analyzed by pyrolysis in extractive-free samples to avoid interference of phenolic extractives. The lignin-derived compounds were quantified and presented on a molar basis (Table 2). The lignin-derived compounds accounted for $17.5-25.8 \%$ of the total chromatogram peak area for the different barks, with willow showing the lowest and poplar the highest relative proportion of lignin-derived compounds.

In line with the expectations [99], the pyrolysis of softwood barks of larch and Corsican pine released phenolic compounds derived predominantly from $G$ units (88-91 mol\% of all lignin compounds), with guaiacol, 4methylguaiacol and 4-vinylguaiacol being the predominant ones, also presenting lower amounts of $\mathrm{H}$ units and 
showing absence of $\mathrm{S}$ units, as typical of softwoods. The hardwood barks showed a predominance of $\mathrm{G}$ units (53-69 mol\%) in relation to $S$ units (20-38 mol\%) and also presenting lower amount of $H$ units (5-15 mol\%). The low S/G ratio implies a more condensed lignin structure for hardwood barks when compared to typical values for woods that tend to have $S / G$ ratios above one.[100] This variation of relative abundances of $S$ and $G$ units between wood and bark has been previously reported for several species.[74, 101]

The relative abundance of $\mathrm{H}$ units is quite high for most species (10-15 mol\%), with exception for the red oak (5 mol\%). The true $\mathrm{H}$ unit content, derived from $p$-coumaryl alcohol, is rarely above $5 \mathrm{~mol} \%$ but has been often overestimated, mostly due to $p$-coumarate and $p$-hydroxybenzoate units that upon pyrolysis undergo decarboxylation, thus being released and accounted for as $\mathrm{H}$ units.[102] This is especially true for poplar and willow species, which are known to have $p$-hydroxybenzoate groups acetylated to their lignin structure[102], possibly explaining the large share of $\mathrm{H}$ units in the respective barks. Another possibility is the occurrence of demethoxylation reactions of $\mathrm{S}$ and $\mathrm{G}$ units to $\mathrm{H}$ units which might occur at temperatures above $400-450^{\circ} \mathrm{C}$.[103] Nevertheless, for some barks, such high $\mathrm{H}$ contents are valid and confirmed by NMR techniques (e.g. $22 \mathrm{~mol} \% \mathrm{H}$ content by pyrolysis for Picea abies bark corresponded to $14 \mathrm{~mol} \%$ by 2D-HSQC-NMR).[44]

Bark lignins can be fairly similar to their respective wood (as for E. globulus) with a similar overall content, aromatic units distribution and inter-unit linkages types[44] or, on the contrary, present highly differentiating chemical characteristics, whether by having higher overall lignin content (as it happens here for Corsican pine, table 1), presenting specific monomers not seen in wood lignins (e.g. hydroxystilbenes glucosides in Picea abies[104]) or having high content in $p$-hydroxycinnamates (as in Acacia melanoxylon bark[44]).

From a biorefinery point of view, the $\mathrm{S} / \mathrm{G}$ ratio of lignin is a major factor influencing its valorization.[105] A higher $\mathrm{S}$ content tends to correspond to a higher fraction of inter-unit ether bonds ( $\beta-0-4)$, which are readily cleaved during lignin depolymerization.[20, 106] A higher $\mathrm{G}$ content, as reported for these hardwood barks, tends to yield fewer monomers upon depolymerization. [20,106] As for the high $\mathrm{H}$ unit abundance of some barks, it might indicate a high $p$-benzoate or $p$-coumarate content, which could make them an interesting source of these compounds that are also present in grass lignins.[20]

Table 2: Identities and relative molar abundances of lignin derived phenolic compounds obtained via Py-GC/MS of the different, extractive-free barks. Also the H, G and S molar percentages and the S/G ratio are displayed. For more details on the calculations, the reader is referred to the section 'Materials and methods'.

\begin{tabular}{|c|c|c|c|c|c|c|}
\hline Compound & Poplar & Red oak & Black locust & Willow & $\begin{array}{c}\text { Corsican } \\
\text { pine }\end{array}$ & Larch \\
\hline phenol & 7.1 & 3.0 & 5.4 & 10.4 & 6.7 & 5.1 \\
\hline guaiacol & 9.8 & 6.5 & 7.8 & 8.0 & 12.1 & 11.2 \\
\hline 4-methylphenol & 3.2 & 1.7 & 5.4 & 4.6 & 5.0 & 3.6 \\
\hline 4-methylguaiacol & 10.3 & 5.1 & 1.6 & 5.8 & 14.9 & 13.1 \\
\hline 4-ethylphenol & 0.7 & 0.4 & 2.5 & 0.4 & 0.8 & 0.8 \\
\hline 4-ethylguaiacol & 2.0 & 1.1 & 1.3 & 0.9 & 2.7 & 2.2 \\
\hline 4-vinyl guaiacol & 16.3 & 13.8 & 14.9 & 15.9 & 19.5 & 18.3 \\
\hline eugenol & 2.1 & 2.0 & 1.7 & 1.5 & 2.5 & 2.7 \\
\hline 4-propylguaiacol & 0.6 & 0.5 & 0.4 & 0.3 & 0.7 & 0.7 \\
\hline syringol & 3.0 & 4.7 & 4.3 & 4.0 & - & - \\
\hline cis-isoeugenol & 1.6 & 1.4 & 1.8 & 1.5 & 1.9 & 2.3 \\
\hline trans-isoeugenol & 6.8 & 5.3 & 5.4 & 6.0 & 7.6 & 8.7 \\
\hline 4- methylsyringol & 3.3 & 4.2 & 4.1 & 4.1 & - & - \\
\hline vanillin & 4.4 & 4.0 & 3.9 & 3.2 & 3.8 & 5.1 \\
\hline \multicolumn{7}{|l|}{ (4-hydroxy-3- } \\
\hline methoxyphenyl)propyne & 3.1 & 3.8 & 3.2 & 4.0 & 2.8 & 3.0 \\
\hline homovanillin & 0.9 & 1.5 & 0.1 & 0.2 & 2.2 & 2.5 \\
\hline
\end{tabular}




\begin{tabular}{|c|c|c|c|c|c|c|}
\hline 4-ethylsyringol & 0.5 & 0.6 & 0.7 & 0.8 & - & - \\
\hline acetoguaiacone & 3.0 & 2.5 & 1.8 & 2.1 & 3.1 & 3.1 \\
\hline 4-vinylsyringol & 3.7 & 6.5 & 6.7 & 7.0 & - & - \\
\hline guaiacylacetone & 1.3 & 1.1 & 1.8 & 0.8 & 1.4 & 1.3 \\
\hline 4-allylsyringol & 0.9 & 1.9 & 1.5 & 1.3 & - & - \\
\hline propiovanillone & 0.9 & 0.4 & 0.6 & 0.4 & 2.4 & 2.0 \\
\hline coniferyl alcohol & 1.0 & 1.7 & 0.6 & 0.2 & 1.2 & 1.8 \\
\hline cis-4-propenylsyringol & 0.7 & 1.2 & 1.5 & 1.2 & - & - \\
\hline 4-propinylsyringol & 0.4 & 1.2 & 1.0 & 0.9 & - & - \\
\hline trans-4-propenylsyringol & 2.7 & 5.5 & 5.2 & 5.0 & - & - \\
\hline dihydroconiferyl alcohol & 0.1 & 1.3 & - & & 2.2 & 3.1 \\
\hline syringaldehyde & 1.4 & 4.1 & 2.7 & 2.1 & - & - \\
\hline cis-coniferyl alcohol & 0.7 & 0.7 & 0.7 & 0.2 & 0.3 & 1.0 \\
\hline homosyringaldehyde & - & 0.6 & - & & - & - \\
\hline acetosyringone & 1.4 & 2.1 & 2.2 & 1.8 & - & - \\
\hline trans-coniferyl alcohol & 1.0 & 1.4 & 3.0 & & 0.4 & 2.0 \\
\hline trans-coniferaldehyde & 3.4 & 3.2 & 2.0 & 2.7 & 5.6 & 6.5 \\
\hline syringylacetone & 0.6 & 1.1 & 1.1 & 1.1 & - & - \\
\hline propiosyringone & 0.2 & 0.4 & 0.3 & 0.1 & - & - \\
\hline syringyl vinyl ketone & 0.1 & 0.3 & 0.1 & 0.1 & - & - \\
\hline sinapyl alcohol & - & 0.3 & - & 0.1 & - & - \\
\hline trans-sinapaldehyde & 1.0 & 3.1 & 2.4 & 1.3 & - & - \\
\hline $\mathrm{H}(\mathrm{mol} \%)$ & 10.9 & 5.1 & 13.3 & 15.3 & 12.5 & 9.5 \\
\hline $\mathrm{G}(\mathrm{mol} \%)$ & 69.1 & 57.2 & 52.7 & 53.5 & 87.5 & 90.5 \\
\hline $\mathrm{S}$ (mol\%) & 19.9 & 37.7 & 34.0 & 31.1 & - & - \\
\hline $\mathrm{S} / \mathrm{G}$ ratio & 0.3 & 0.7 & 0.6 & 0.6 & - & - \\
\hline
\end{tabular}

\section{Lipophilic extractives}

The composition of the lipophilic dichloromethane (DCM) extracts of the various barks were analyzed by GC/MS after trimethylsilylation. Although DCM extracts are not the major group of extractives (representing between $9.2 \%$ up to $30.7 \%$ of the total extractives, Table 1) they have a rich chemical diversity and often include compounds with interesting bioactivities and properties. Because of the low volatility of most compounds present in the ethanol and water extracts, such GC/MS analysis was not carried out for these extracts but a chemical determination of phenolic families was made instead (see next section).

An overview of the identified compound classes is presented in table 3. For the detailed table containing the individual identified molecules, the reader is referred to table S1 (Supplementary information). For comparison with data presented here, the reader is also referred to other studies on the lipophilic bark extracts of the same species or genus: different Salix species[107], Populus tremuloides[108], Quercus faginea[109], Pinus species[110, 111], Larix decidua[50].

From the results in table 3 , it is clear that the aliphatic monoacids present a large share of the DCM extractives. For the hardwood barks, it is the most abundant class, whereas for softwood barks, it is the second-most abundant class of compounds. Aliphatic monoacids are highly prevalent in the bark of red oak, in which they comprise $56.6 \%$ of the total DCM extractives, identifiable by GC/MS. A previous study also demonstrated a high content of alkanoic acids in the DCM extracts of the bark of Quercus faginea.[109] Furthermore, red oak also has the highest fraction of DCM extracts ( $7.4 \mathrm{wt} \%$ ) on a dry bark basis (vide supra), making it a potential source of extractable fatty acids. One aliphatic monoacid, 9,12-octadecadienoic acid, was specifically abundant in red oak, making up $29.4 \%$ of the DCM extractives. In fact, unsaturated C18 acids (C18:1, C18:2 and C18:3) make up a large share in the DCM extracts of all the hardwood barks (12.5 - 40\%), but they were significantly less abundant in the softwood DCM extracts (<4\%). In 
the softwood barks, saturated aliphatic acids were more common. For instance, a large share of docosanoic acid (C22:0, 13.9\%) and eicosanoic acid (C20:0, 6.4\%) was observed in the DCM extracts of Corsican pine.

Aliphatic alcohols were much less abundant than the aliphatic monoacids. The DCM extract of poplar bark, however, still presents a high share of these aliphatic alcohols (12.6\%). The diacids and hydroxyacids, both presenting multiple functional groups, were found chiefly in the hardwood barks, especially in black locust bark (10.9\%). Also monoacylglycerols were found predominantly in hardwood barks, with poplar having the largest share of them.

Alkyl hydroxycinnamates (coumarates, ferulates and caffeates) were encountered mainly in poplar and black locust, 5.4 and $9.2 \%$ of DCM extractives, respectively. Alkyl coumarates and ferulates were found in poplar, whereas alkyl caffeates and ferulates were detected in black locust bark. Such long-chain alkyl hydroxycinnamates are interesting compounds in view of their anticancer activity.[112]

Diterpenoids ( $C_{20}$ terpenoids) were the most abundant class in the softwood barks of Corsican pine and larch, representing respectively 35.9 and $48.7 \%$ of the identifiable DCM extractives. Within this class of molecules, pimaric acid, isopimaric acid, abietic acid and dehydro abietic acid, which are all resin acids, were dominant. Hardwood barks did not contain any diterpenoids. Triterpenoids ( $C_{30}$ terpenoids) were observed for all barks $(4.8-14.9 \%)$, as many of these molecules are common phytosterols. The phytosterol $\beta$-sitosterol was the most common triterpenoid and was found in all barks. Indeed, triterpenoids are an important fraction of the lipophilic extracts, as previous studies on Eucalyptus globulus bark and stump bark demonstrated.[113, 114] Sesquiterpenoids ( $C_{15}$ terpenoids) were only found in the bark of red oak, where they make up 9.1\% of DCM extractives. Such sesquiterpenoids were also detected in the bark of Eucalyptus globulus.[113]

Carbohydrate (derivatives) were mainly encountered in the DCM extracts of willow bark (20.0\%). In most cases, these molecules could not be conclusively identified by GC/MS. However, it does highlight the high content of free carbohydrates or carbohydrate linked to other monomeric moieties (e.g. phenolics) in the bark of willow.

Flavonoids were detected almost exclusively in the lipophilic extract of poplar bark, with one specific flavonoid compound detected in a very large quantity (15.5\%). Although we were unable to conclusively identify this compound, we tentatively suggest 7-0-methyl taxifolin. The MS pattern of its trimethylsilylated analogue is depicted in Fig. S10. Sakuranetin, which is structurally similar to 7-0-methyl taxifolin, was found in a small amount in poplar bark. This compound is the non-glycosylated analogue of sakuranin, which has been detected and reported previously in a study on poplar bark.[108]

Table 3: Composition of dichloromethane extracts of the different barks. The identified compounds were grouped and their combined peak area was expressed as \% of the total chromatographic peak area in the total ion current (TIC), as obtained by GC/MS. The complete identification of all the individual compounds is presented in table S1.

\begin{tabular}{|c|c|c|c|c|c|c|}
\hline & Poplar & Red oak & Black locust & Willow & $\begin{array}{c}\text { Corsican } \\
\text { pine }\end{array}$ & Larch \\
\hline Aliphatic monoacid & 33.8 & 56.6 & 47.9 & 38.7 & 30.6 & 16.6 \\
\hline Aliphatic alcohol & 12.6 & 1.1 & 4.9 & 1.7 & 1.6 & 4.8 \\
\hline Hydroxyacid & 1.5 & 0.7 & 5.3 & 0.9 & & \\
\hline Diacid & 1.0 & 2.4 & 5.6 & 1.9 & 0.3 & 0.2 \\
\hline Monoacylglycerol & 5.3 & 1.9 & 2.0 & 1.8 & 0.5 & 1.3 \\
\hline Alkyl hydroxycinnamate & 5.4 & & 9.2 & 0.2 & 1.2 & 2.9 \\
\hline Sesquiterpenoid & & 9.1 & & & & \\
\hline Diterpenoid & & & & & 35.9 & 48.7 \\
\hline Triterpenoid & 8.2 & 6.7 & 14.9 & 7.6 & 8.2 & 4.8 \\
\hline Carbohydrate (derivative) & 0.3 & & & 20.0 & & \\
\hline Flavonoid & 15.9 & 0.3 & & & & \\
\hline
\end{tabular}




\begin{tabular}{lcccccc} 
Phenolic & 4.6 & 1.1 & 0.7 & 1.2 & 1.8 & 0.2 \\
Other & 5.1 & 7.2 & 1.3 & 6.5 & 2.0 & 1.2 \\
& & & & & & \\
Sum identified & 93.7 & 87.2 & 91.8 & 80.2 & 82.1 & 80.6 \\
\hline
\end{tabular}

\section{Phenolic content and antioxidant activity of bark polar extracts}

An ethanol/water $(1 / 1)$ extraction at $50^{\circ} \mathrm{C}$ with sonication was carried out on the different bark samples with the extraction yields shown in table 4. This single extraction step removed most of the polar extractives (as determined via successive soxhlet extractions, table 1). These ethanol/water extracts were then analyzed for their total phenolic, flavonoid and tannin content, as well as for their antioxidant capacity, as shown in table 4.

The total phenolic content is highest in red oak and larch bark extracts, viz. 579 and 573 mg GAE/g extract, respectively. Corsican pine and black locust bark extracts have the lowest phenolic content (265.2 and $286.5 \mathrm{mg}$ GAE/g extract). Flavonoid content is highest in larch and willow (390.9 and $310 \mathrm{mg}$ CE/g extract) and lowest in black locust (177.3 mg CE/g extract). Condensed tannin content varies strongly between bark species with larch presenting the highest values (669.9 mg CE/g extract) and black locust the lowest (88.4 mg CE/g extract). Red oak and Corsican pine barks have similar condensed tannin content despite red oak having twice as many phenolics, meaning that the majority of phenolics in red oak do not originate from condensed tannins. Indeed, oak barks tend to contain substantial amounts of hydrolysable tannins, explaining their high phenolic but lower condensed tannin content.[115]

Despite being important to know and understand the characteristics of the extracts obtained, from a biorefinery point of view it is also important to observe their content on dry bark basis, therefore taking into account not only the extracts composition but also their extraction yield. Although different extraction processes and conditions might alter the extraction yield and product composition, the values obtained here can serve as a point of reference.

On a dry bark basis, larch has the highest total phenolic, flavonoids and condensed tannins of the six barks studied. Besides having the high extraction yield (26.1 wt\%), the extracts obtained are also enriched in phenolic molecules. The abundance of condensed tannins present in this bark (168 mg CE/g bark) shows an interesting potential to be sourced for condensed tannins.[116] Willow presented the second highest total phenolic content on a dry bark basis (102.6 mg GAE/g bark), which could be linked to anatomical observation of phenolic deposits in the cell lumens of the rhytidome of willow bark (Fig. S6.1 B D; Fig. S6.2A). Comparing the results of red oak and black locust bark with a previous report on the same bark species, the differences are striking. The extraction yields (17.3 and 9.5 wt\%, respectively) are much higher than those presented by Sillero et al. (3.2 and $3.1 \mathrm{wt} \%$ ), and the total phenolic content of these extracts was higher in this study (579 and $286.5 \mathrm{mg} \mathrm{GAE} / \mathrm{g}$ extract) compared to those previously reported (276.5 and $178.1 \mathrm{mg} \mathrm{GAE} / \mathrm{g}$ extract).[89] In this study, the total amount of phenolics extracted, on a dry bark basis, is thus over 11 times higher for red oak and almost 5 times higher for black locust compared to Sillero et al., highlighting the formidable intra-species differences that will likely be influenced by tree age and health condition, and edaphoclimatic environment among other factors.[14, 89] Comparing the results obtained in this study with previous results of barks from different tree species (Eucalyptus globulus, Picea abies, Acacia melanoxylon and Acacia dealbata) shows that the total phenolics and condensed tannins on dry bark basis largely fall within the same range, and the inter-species variability is high.[49]

The antioxidant activity of the ethanol/water bark extracts was screened using the FRAP assay [73] and the DPPH inhibition assay.[72] The FRAP antioxidant activity for all barks fell within a 500-1200 mg TE/g extract interval, with red oak showing the highest and black locust the lowest value. By using trolox (a synthetic antioxidant analog to vitamin E) as standard, it was verified that the extracts possess very good capacity to counter a metal ion oxidation, 
with the lowest results showing half the trolox antioxidant activity, while red oak extract gave even higher antioxidant activity than this known standard. The values reported here are higher than those reported by Sillero et al. for six different barks species (146.1 - $640.3 \mathrm{mg}$ TE/g extract).[89] As a point of reference, Neiva et al. reported antioxidant activities within the range of $300-1300 \mathrm{mg} \mathrm{TE} / \mathrm{g}$ extract for their ethanol and water extracts of four different barks.[49]

Free radical scavenging capacity was analyzed via the DPPH inhibition assay.[72] The results are expressed as $\mathrm{IC}_{50}$ values, which represents the concentration of extract solution needed to achieve $50 \%$ DPPH inhibition. Since this $\mathrm{IC}_{50}$ is dependent on the concentration of the DPPH solution used in the test, the antioxidant activity index (AAI) was calculated as well.[72] According to the definitions used by Scherer et al.,[72] all bark extracts displayed very strong antioxidant activity (AAI > 2). Red oak and larch have the highest AAI ( 5.5 and 5.2, respectively) whereas black locust has the lowest AAI (2.2). The results are comparable to the AAI obtained for eucalyptus and spruce barks (both 3.7) $[66,68]$, but are still lower than known antioxidant compounds such as trolox (6.9) and gallic acid (23.4). The AAls of trolox and gallic acid, measured here, are in good agreement with those previously reported by Luís et al. (6.62 and 22.77 respectively) and Neiva et al. (6.7 and 23.6), indicating the robustness of the analytical procedure.[49, 66, 117]

Table 4: Chemical analysis (phenolics, flavonoids and condensed tannins) and antioxidant activities (FRAP and DPPH) of the ethanol/water extracts of different bark species. Extraction conditions: $1 \mathrm{~g}$ bark, $10 \mathrm{~mL}$ ethanol/water (1:1), $1 \mathrm{~h}$, sonication at $50^{\circ} \mathrm{C}$. Gallic acid, catechin and Trolox were used as standard in the different assays. Results are therefore expressed in GAE (gallic acid equivalent), CE (catechin equivalent) and TE (trolox equivalent). ${ }^{*} I C_{50}=$ extract concentration required for $50 \%$ DPPH inhibition; Trolox $I C_{50}=3.4 \mathrm{mg} / \mathrm{mL}$ and gallic acid $I C_{50}=1.0 \mathrm{mg} / \mathrm{mL} .{ }^{* *} A A I$ (antioxidant activity index) $=$ final $D P P H$ concentration $/ I C_{50} ;$ Trolox $A A I=6.9$ and gallic acid $A A I=23.4$.

\begin{tabular}{|c|c|c|c|c|c|c|}
\hline & Poplar & Red oak & Black locust & Willow & Corsican pine & Larch \\
\hline Extraction yield (wt\%) & 16.8 & 17.3 & 9.5 & 23.8 & 11.1 & 26.1 \\
\hline \multicolumn{7}{|l|}{ Phenolics } \\
\hline mg GAE / g extract & $369.9 \pm 2.9$ & $579 \pm 20$ & $286.5 \pm 3.2$ & $477.9 \pm 19.8$ & $265.2 \pm 3.1$ & $573 \pm 16.1$ \\
\hline mg GAE / g bark & $56 \pm 0.4$ & $91.9 \pm 3.2$ & $25.3 \pm 0.3$ & $102.6 \pm 4.2$ & $27.9 \pm 0.3$ & $143.7 \pm 4$ \\
\hline \multicolumn{7}{|l|}{ Flavonoids } \\
\hline $\mathrm{mg}$ CE / g extract & $294.8 \pm 20.7$ & $238.9 \pm 4.9$ & $177.3 \pm 1.4$ & $310 \pm 7.4$ & $253.6 \pm 3.6$ & $390.9 \pm 12.6$ \\
\hline $\mathrm{mg}$ CE / g bark & $44.6 \pm 3.1$ & $37.9 \pm 0.8$ & $15.6 \pm 0.1$ & $66.6 \pm 1.6$ & $26.7 \pm 0.4$ & $98 \pm 3.2$ \\
\hline \multicolumn{7}{|l|}{ Tannins } \\
\hline $\mathrm{mg}$ CE / g extract & $140.1 \pm 1.6$ & $354.8 \pm 5$ & $88.4 \pm 0.5$ & $608.4 \pm 4.2$ & $363.2 \pm 3$ & $669.9 \pm 13.4$ \\
\hline $\mathrm{mg}$ CE / g bark & $21.2 \pm 0.2$ & $56.3 \pm 0.8$ & $7.8 \pm 0$ & $130.7 \pm 0.9$ & $38.2 \pm 0.3$ & $168 \pm 3.4$ \\
\hline \multicolumn{7}{|l|}{ FRAP } \\
\hline mg TE / g extract & $626.8 \pm 11$ & $1208.6 \pm 18.8$ & $500.5 \pm 11.3$ & $921.2 \pm 23.5$ & $677.1 \pm 1.4$ & $840.5 \pm 37.9$ \\
\hline $\mathrm{mg} \mathrm{TE} / \mathrm{g}$ bark & $94.9 \pm 1.7$ & $191.9 \pm 3$ & $44.2 \pm 1$ & $197.8 \pm 5.1$ & $71.3 \pm 0.1$ & $210.8 \pm 9.5$ \\
\hline $\mathrm{mg} \mathrm{GAE} \mathrm{/} \mathrm{g} \mathrm{extract}$ & $141.3 \pm 2.5$ & $272 \pm 4.2$ & $112.8 \pm 2.5$ & $207.3 \pm 5.3$ & $152.7 \pm 0.3$ & $189.2 \pm 8.5$ \\
\hline mg GAE / g bark & $21.4 \pm 0.4$ & $43.2 \pm 0.7$ & $10 \pm 0.2$ & $44.5 \pm 1.1$ & $16.1 \pm 0$ & $47.4 \pm 2.1$ \\
\hline \multicolumn{7}{|l|}{ DPPH } \\
\hline $\mathrm{C}_{50}(\mathrm{mg} / \mathrm{L})^{*}$ & 8.7 & 4.2 & 10.4 & 6.5 & 7.3 & 4.5 \\
\hline $\mathrm{AAl}{ }^{* *}$ & 2.7 & 5.5 & 2.2 & 3.6 & 3.2 & 5.2 \\
\hline
\end{tabular}

\section{Valorization potential}

A large variety of compounds can be found in barks - with a profound diversity between different species - as illustrated in the preceding sections, thereby leading to a potential chemical valorization of barks. Several valorization opportunities and processing flows can be envisioned based on the specific chemical and structural 
features of the targeted barks. Some of them are briefly discussed here, although a thorough evaluation of these opportunities falls outside the scope of this paper.

The chemical composition of these barks revealed a high content of extractives (14-30 wt\%) which constitutes a prime valorization step. In the lipophilic extractives that can be extracted using apolar solvents, like DCM or light naphtha, resin acids are potentially interesting as they can be extracted in relatively large quantity from larch and Corsican pine bark and could provide an alternative to the tall oil produced as by-product from coniferous wood in the Kraft process.[118] In poplar bark, the tentatively identified monoflavonoid (7-0-methyl taxifolin) that was observed in a large proportion, might have potentially interesting bioactive properties. Also the alkyl hydroxycinnamates found in poplar and black locust bark might be used in view of their anticancer activity.[112]

The polar extractives, extracted via a single ethanol/water extraction, also possess interesting properties. As their yield is much higher (up to $26 \mathrm{wt} \%$ for larch), valorization may be easier. For instance, the extracts of red oak, willow and larch are especially rich in phenolic compounds, potentially having antimicrobial properties.[49, 119] Alternatively, these phenolic moieties also impart excellent antioxidant activities - even comparable to trolox - to these extracts. One could thus envision them being used as antioxidant in applications such as lubricants or rubbers.

Suberin content was low in most of these barks, although for black locust the proportion $(10.3 \mathrm{wt} \%$, table 1) might advise the study of a chemical valorization of the fatty acids and alcohols e.g. after an alkaline depolymerization. In all cases the barks after fractionation of extractives are a lignocellulosic material that may undergo further thermal or chemical processing.

\section{Conclusion}

The barks of six relevant tree species in Europe were anatomically and chemically characterized in view of their potential use in a biorefinery. Anatomical characterization showed the fundamental cell types and their arrangement in phloem, periderm and rhytidome, and the distinction among them was quite clear. Barks with highly lignified cells were found in R. pseudoacacia, P. canadensis and Salix sp. (e.g. fibers in tangential bands), Q. rubra (e.g. abundant clusters of sclereids) or L. decidua (e.g. fibrosclereids). In contrast, fibers were absent in P. nigra. R. pseudoacacia bark contained a conspicuous amount of phellem cells in the periderms. Abundant crystalliferous parenchyma was reported for Salix sp., $Q$. rubra and $R$. pseudoacacia. Phenolic deposits were common in all barks in phloem parenchyma cells and sclereids and especially in the rhytidome (e.g. Salix sp. or P. nigra). Resin ducts were observed in both gymnosperms.

Chemical characterization highlighted the differences in composition between the different bark species. All barks present a high extractive content (14 to $30 \mathrm{wt} \%$ ) with larch and willow bark being the richest in extractives. Black locust bark contains a substantial amount of suberin, in line with its substantial proportion of suberized phellem cells in the periderms, making it an interesting resource for suberin valorization. The lignin content ranges from 22 to 29 wt\% for all barks, except for Corsican pine (45 wt\%). Pyrolysis results showed that hardwood bark lignin is much richer in $\mathrm{G}$ than in $\mathrm{S}$ units, with low $\mathrm{S} / \mathrm{G}$ ratios. This implies a more condensed lignin structure in hardwood barks compared to their woods, pointing to a lower susceptibility towards depolymerization. The content of $\mathrm{H}$ units was high in the bark lignins (5-15\%). The barks had a low holocellulose content (34.6 to $44.5 \mathrm{wt} \%$ ) and the main hemicellulosic monosaccharides were xylose in hardwood and mannose in softwood barks. The low polysaccharide content suggests that a possible biorefinery process should focus primarily on the extractives and lignin fractions for these barks.

The lipophilic extracts contained predominantly fatty acids in hardwood barks, and resin acids in softwood barks. Next to these compounds, triterpenoids also constituted an important class of the lipophilic extractives in all barks. 
The polar extracts of the barks presented a high inter-species variability with larch bark showing the highest phenolics, flavonoids and condensed tannins content, suggesting its use as a resource for the targeted extraction and valorization of these compounds. All bark extracts exhibited strong antioxidant activities, especially red oak, larch and willow bark extracts, making them interesting additives for industrial antioxidant applications.

Overall, the results demonstrate the strong anatomical and chemical variability between barks of different species. This suggests that biorefining processes will need to be tailored for the valorization of specific bark streams and that the product outcome in a biorefinery will be strongly dependent on the choice of the bark feedstock.

\section{Acknowledgements}

The Forest Research Center (CEF) was financed by Fundação para a Ciência e a Tecnologia (FCT), Portugal (UIDB/00239/2020). This work was performed in the framework of Catalisti-SBO project BIOWOOD and EoS project BIOFACT. T. V. acknowledges the Research Foundation Flanders (FWO Vlaanderen) for a doctoral fellowship and travel grant (1S64017N and V417219N). D. M. N. acknowledges a SUSFOR doctoral PhD scholarship from FCT (PD/BD/52697/2014). B. S. acknowledges EoS project BIOFACT and Catalisti-SBO project BIOWOOD for continuation of financial support for biorefinery research.

\section{References}

[1] Y. Liao, S.-F. Koelewijn, G. Van den Bossche, J. Van Aelst, S. Van den Bosch, T. Renders, K. Navare, T. Nicolaï, K. Van Aelst, M. Maesen, A sustainable wood biorefinery for low-carbon footprint chemicals production, Science, 367 (2020) 1385-1390.

[2] A.J. Ragauskas, C.K. Williams, B.H. Davison, G. Britovsek, J. Cairney, C.A. Eckert, W.J. Frederick, J.P. Hallett, D.J. Leak, C.L. Liotta, The path forward for biofuels and biomaterials, Science, 311 (2006) 484-489.

[3] J. H. Clark, F. E. I. Deswarte, T. J. Farmer, The integration of green chemistry into future biorefineries, Biofuels, Bioproducts and Biorefining, 3 (2009) 72-90.

[4] F.H. Isikgor, C.R. Becer, Lignocellulosic biomass: a sustainable platform for the production of bio-based chemicals and polymers, Polymer Chemistry, 6 (2015) 4497-4559.

[5] A. Corma, S. Iborra, A. Velty, Chemical routes for the transformation of biomass into chemicals, Chemical Reviews, 107 (2007) 2411-2502.

[6] B.M. Upton, A.M. Kasko, Strategies for the Conversion of Lignin to High-Value Polymeric Materials: Review and Perspective, Chemical Reviews, 116 (2016) 2275-2306.

[7] I. Delidovich, P.J.C. Hausoul, L. Deng, R. Pfützenreuter, M. Rose, R. Palkovits, Alternative Monomers Based on Lignocellulose and Their Use for Polymer Production, Chemical Reviews, 116 (2016) 1540-1599. [8] H.R. Ghatak, Biorefineries from the perspective of sustainability: Feedstocks, products, and processes, Renewable and Sustainable Energy Reviews, 15 (2011) 4042-4052.

[9] J.M. Harkin, J.W. Rowe, Bark and its possible uses, (Research note FPL; 091): 56 p., 91 (1971).

[10] S. Feng, S. Cheng, Z. Yuan, M. Leitch, C.C. Xu, Valorization of bark for chemicals and materials: A review, Renewable and Sustainable Energy Reviews, 26 (2013) 560-578.

[11] W. Stafford, W. De Lange, A. Nahman, V. Chunilall, P. Lekha, J. Andrew, J. Johakimu, B. Sithole, D. Trotter, Forestry biorefineries, Renewable Energy, (2020).

[12] R.F. Evert, Esau's plant anatomy: meristems, cells, and tissues of the plant body: their structure, function, and development, John Wiley \& Sons2006.

[13] V. Angyalossy, M.R. Pace, R.F. Evert, C.R. Marcati, A.A. Oskolski, T. Terrazas, E. Kotina, F. Lens, S.C. Mazzoni-Viveiros, G. Angeles, S.R. Machado, A. Crivellaro, K.S. Rao, L. Junikka, N. Nikolaeva, P. Baas, IAWA List of Microscopic Bark Features, IAWA Journal, 37 (2016) 517. 
[14] R.M. Rowell, R. Pettersen, J.S. Han, J.S. Rowell, M.A. Tshabalala, Cell wall chemistry, Handbook of wood chemistry and wood composites, CRC Press2005, pp. 35-74.

[15] E.F. Kurth, The Chemical Composition of Barks, Chemical Reviews, 40 (1947) 33-49.

[16] I. Delidovich, K. Leonhard, R. Palkovits, Cellulose and hemicellulose valorisation: an integrated challenge of catalysis and reaction engineering, Energy \& Environmental Science, 7 (2014) 2803-2830.

[17] S. Van de Vyver, J. Geboers, P.A. Jacobs, B.F. Sels, Recent advances in the catalytic conversion of cellulose, ChemCatChem, 3 (2011) 82-94.

[18] R. Rinaldi, F. Schüth, Acid hydrolysis of cellulose as the entry point into biorefinery schemes, ChemSusChem, 2 (2009) 1096-1107.

[19] S. Takkellapati, T. Li, M.A. Gonzalez, An overview of biorefinery-derived platform chemicals from a cellulose and hemicellulose biorefinery, Clean technologies and environmental policy, 20 (2018) 16151630.

[20] W. Schutyser, T. Renders, S. Van den Bosch, S.F. Koelewijn, G.T. Beckham, B.F. Sels, Chemicals from lignin: an interplay of lignocellulose fractionation, depolymerisation, and upgrading, Chemical Society Reviews, 47 (2018) 852-908.

[21] R. Rinaldi, R. Jastrzebski, M.T. Clough, J. Ralph, M. Kennema, P.C. Bruijnincx, B.M. Weckhuysen, Paving the way for lignin valorisation: recent advances in bioengineering, biorefining and catalysis, Angew. Chem. Int. Ed., 55 (2016) 8164-8215.

[22] Z. Sun, B. Fridrich, A. de Santi, S. Elangovan, K. Barta, Bright Side of Lignin Depolymerization: Toward New Platform Chemicals, Chemical Reviews, 118 (2018) 614-678.

[23] P. Azadi, O.R. Inderwildi, R. Farnood, D.A. King, Liquid fuels, hydrogen and chemicals from lignin: A critical review, Renewable and Sustainable Energy Reviews, 21 (2013) 506-523.

[24] T. Renders, G. Van den Bossche, T. Vangeel, K. Van Aelst, B. Sels, Reductive catalytic fractionation: state of the art of the lignin-first biorefinery, Curr. Opin. Biotechnol., 56 (2019) 193-201.

[25] M.V. Galkin, J.S. Samec, Lignin Valorization through Catalytic Lignocellulose Fractionation: A Fundamental Platform for the Future Biorefinery, ChemSusChem, 9 (2016) 1544-1558.

[26] G. Koumba-Yoya, T. Stevanovic, Transformation of sugar maple bark through catalytic organosolv pulping, Catalysts, 7 (2017) 294.

[27] L.-Y. Liu, S.C. Patankar, R.P. Chandra, N. Sathitsuksanoh, J.N. Saddler, S. Renneckar, Valorization of Bark Using Ethanol-Water Organosolv Treatment: Isolation and Characterization of Crude Lignin, ACS Sustainable Chemistry \& Engineering, 8 (2020) 4745-4754.

[28] A. Romaní, A. Larramendi, R. Yáñez, Á. Cancela, Á. Sánchez, J.A. Teixeira, L. Domingues, Valorization of Eucalyptus nitens bark by organosolv pretreatment for the production of advanced biofuels, Industrial Crops and Products, 132 (2019) 327-335.

[29] D.M. Neiva, R.A. Costa, J. Gominho, S. Ferreira-Dias, H. Pereira, Fractionation and valorization of industrial bark residues by autohydrolysis and enzymatic saccharification, Bioresource Technology Reports, (2020) 100441.

[30] R. Torget, M.E. Himmel, K. Grohmann, Dilute sulfuric acid pretreatment of hardwood bark, Bioresource Technology, 35 (1991) 239-246.

[31] M. Normark, S. Winestrand, T.A. Lestander, L.J. Jönsson, Analysis, pretreatment and enzymatic saccharification of different fractions of Scots pine, BMC biotechnology, 14 (2014) 20.

[32] T. Vangeel, T. Renders, K. Van Aelst, E. Cooreman, S. Van den Bosch, G. Van den Bossche, S.-F. Koelewijn, C. Courtin, B. Sels, Reductive catalytic fractionation of black locust bark, Green Chem., 21 (2019) 5841-5851.

[33] I. Kumaniaev, J.S.M. Samec, Valorization of Quercus suber Bark toward Hydrocarbon Bio-Oil and 4Ethylguaiacol, ACS Sustainable Chemistry \& Engineering, 6 (2018) 5737-5742.

[34] M.D. Garrett, S.C. Bennett, C. Hardacre, R. Patrick, G.N. Sheldrake, New methods in biomass depolymerisation: catalytic hydrogenolysis of barks, RSC Advances, 3 (2013) 21552-21557. 
[35] H. Pereira, Cork: biology, production and uses, Elsevier2007.

[36] C. Leite, H. Pereira, Cork-containing barks-a review, Frontiers in Materials, 3 (2017) 63.

[37] A. Şen, I. Miranda, S. Santos, J. Graça, H. Pereira, The chemical composition of cork and phloem in the rhytidome of Quercus cerris bark, Industrial Crops and Products, 31 (2010) 417-422.

[38] S. Cardoso, J. Ferreira, T. Quilhó, H. Pereira, Cork of Douglas-fir bark: impact of structural and anatomical features on usage, Industrial Crops and Products, 99 (2017) 135-141.

[39] J.P. Ferreira, T. Quilhó, H. Pereira, Characterization of Betula pendula outer bark regarding cork and phloem components at chemical and structural levels in view of biorefinery integration, Journal of Wood Chemistry and Technology, 37 (2017) 10-25.

[40] G.S. Mota, C.J. Sartori, J. Ferreira, I. Miranda, T. Quilhó, F.A. Mori, H. Pereira, Cellular structure and chemical composition of cork from Plathymenia reticulata occurring in the Brazilian Cerrado, Industrial Crops and Products, 90 (2016) 65-75.

[41] A.F. Sousa, A. Gandini, A.J. Silvestre, C. Pascoal Neto, Synthesis and characterization of novel biopolyesters from suberin and model comonomers, ChemSusChem, 1 (2008) 1020-1025.

[42] I. Kumaniaev, K. Navare, N.C. Mendes, V. Placet, K. Van Acker, J.S. Samec, Conversion of birch bark to biofuels, Green Chem., 22 (2020) 2255-2263.

[43] D. Fengel, G. Wegener, Wood: chemistry, ultrastructure, reactions, Walter de Gruyter1983.

[44] D.M. Neiva, J. Rencoret, G. Marques, A. Gutiérrez, J. Gominho, H. Pereira, J.C. del Rio, Lignin from tree barks: chemical structure and valorization, ChemSusChem, (2020).

[45] I. Miranda, L. Lima, T. Quilhó, S. Knapic, H. Pereira, The bark of Eucalyptus sideroxylon as a source of phenolic extracts with anti-oxidant properties, Industrial Crops and Products, 82 (2016) 81-87.

[46] V.R. Franceschi, P. Krokene, E. Christiansen, T. Krekling, Anatomical and chemical defenses of conifer bark against bark beetles and other pests, New Phytologist, 167 (2005) 353-376.

[47] P. Rohdewald, A review of the French maritime pine bark extract (Pycnogenol), a herbal medication with a diverse clinical pharmacology, International Journal of Clinical Pharmacology and Therapeutics, 40 (2002) 158-168.

[48] A. Nahrstedt, M. Schmidt, R. Jäggi, J. Metz, M.T. Khayyal, Willow bark extract: the contribution of polyphenols to the overall effect, Wiener Medizinische Wochenschrift, 157 (2007) 348-351.

[49] D.M. Neiva, Â. Luís, J. Gominho, F. Domingues, A.P. Duarte, H. Pereira, Bark residues valorization potential regarding antioxidant and antimicrobial extracts, Wood Science and Technology, (2020) 1-27.

[50] M.Z.M. Salem, H.O. Elansary, A.A. Elkelish, A. Zeidler, H.M. Ali, E.-H. Mervat, K. Yessoufou, In vitro bioactivity and antimicrobial activity of Picea abies and Larix decidua wood and bark extracts, BioResources, 11 (2016) 9421-9437.

[51] A. Arbenz, L. Averous, Chemical modification of tannins to elaborate aromatic biobased macromolecular architectures, Green Chem., 17 (2015) 2626-2646.

[52] A. Pizzi, Tannins: major sources, properties and applications, Monomers, polymers and composites from renewable resources, Elsevier2008, pp. 179-199.

[53] C. Lacoste, M. Čop, K. Kemppainen, S. Giovando, A. Pizzi, M.-P. Laborie, M. Sernek, A. Celzard, Biobased foams from condensed tannin extracts from Norway spruce (Picea abies) bark, Industrial Crops and Products, 73 (2015) 144-153.

[54] H.M.T. Hokkanen, T. AhInäs, S. Alakurtti, N. Demidova, J. Fuchs, D. Izotov, H. Kleeberg, S. Koskimies, M. Langat, J. Lynch, ForestSpeCs findings on byproducts of forest industry: could bark be more valuable than timber?, 4th Nordic Wood Biorefinery Conference, NWBC 2012, VTT Technical Research Centre of Finland, 2012, pp. 56-59.

[55] P. Tharakan, T. Volk, L. Abrahamson, E. White, Energy feedstock characteristics of willow and hybrid poplar clones at harvest age, Biomass and Bioenergy, 25 (2003) 571-580. 
[56] T. Sitzia, A. Cierjacks, D. De Rigo, G. Caudullo, Robinia pseudoacacia in Europe: distribution, habitat, usage and threats, European Atlas of Forest Tree Species. Publication office of the European Union, Luxembourg, (2016) 166-167.

[57] D. Vansteenkiste, L. De Boever, J. Van Acker, Alternative processing solutions for red oak (Quercus rubra) from converted forests in Flanders, Belgium, Proceedings of the COST Action E44 Conference on Broad Spectrum Utilization of Wood at BOKU Vienna, Austria, June 14-15, 2005, Universität für Bodenkultur Wien, 2005, pp. 13-26.

[58] C. Enescu, D. de Rigo, G. Caudullo, A. Mauri, T. Houston Durrant, Pinus nigra in Europe: distribution, habitat, usage and threats, European Atlas of Forest Tree Species, 6 (2016) 126-127.

[59] F. Da Ronch, G. Caudullo, W. Tinner, D. de Rigo, Larix decidua and other larches in Europe: distribution, habitat, usage and threats, (2016).

[60] D.J. Brus, G.M. Hengeveld, D.J.J. Walvoort, P.W. Goedhart, A.H. Heidema, G.J. Nabuurs, K. Gunia, Statistical mapping of tree species over Europe, European Journal of Forest Research, 131 (2012) 145-157. [61] M. Pividori, F. Giannetti, A. Barbati, G. Chirici, European Forest Types: tree species matrix, Publ. Off. EU, Luxembourg, 2016.

[62] C. Pollet, B. Jourez, J. Hebert, Natural durability of black locust (Robinia pseudoacacia L.) wood grown in Wallonia, Belgium, Canadian Journal of Forest Research, 38 (2008) 1366-1372.

[63] J. Ball, J. Carle, A. Del Lungo, Contribution of poplars and willows to sustainable forestry and rural development, UNASYLVA-FAO-, 56 (2005) 3.

[64] P. Vallet, C. Meredieu, I. Seynave, T. Bélouard, J.-F. Dhôte, Species substitution for carbon storage: Sessile oak versus Corsican pine in France as a case study, Forest Ecology and Management, 257 (2009) 1314-1323.

[65] A.C. Barbosa, M.R. Pace, L. Witovisk, V. Angyalossy, A new method to obtain good anatomical slides of heterogeneous plant parts, IAWA Journal, 31 (2010) 373-383.

[66] D.M. Neiva, S. Araújo, J. Gominho, A.d.C. Carneiro, H. Pereira, An integrated characterization of Picea abies industrial bark regarding chemical composition, thermal properties and polar extracts activity, PLOS ONE, 13 (2018) e0208270.

[67] I. Miranda, J. Gominho, I. Mirra, H. Pereira, Chemical characterization of barks from Picea abies and Pinus sylvestris after fractioning into different particle sizes, Industrial Crops and Products, 36 (2012) 395400.

[68] D.M. Neiva, S. Araújo, J. Gominho, A.d.C. Carneiro, H. Pereira, Potential of Eucalyptus globulus industrial bark as a biorefinery feedstock: Chemical and fuel characterization, Industrial Crops and Products, 123 (2018) 262-270.

[69] V.L. Singleton, J.A. Rossi, Colorimetry of total phenolics with phosphomolybdic-phosphotungstic acid reagents, American Journal of Enology and Viticulture, 16 (1965) 144-158.

[70] J. Zhishen, T. Mengcheng, W. Jianming, The determination of flavonoid contents in mulberry and their scavenging effects on superoxide radicals, Food Chemistry, 64 (1999) 555-559.

[71] B. Sun, J.M. Ricardo-da-Silva, I. Spranger, Critical factors of vanillin assay for catechins and proanthocyanidins, J. Agric. Food. Chem., 46 (1998) 4267-4274.

[72] R. Scherer, H.T. Godoy, Antioxidant activity index (AAI) by the 2, 2-diphenyl-1-picrylhydrazyl method, Food Chemistry, 112 (2009) 654-658.

[73] I.F. Benzie, J.J. Strain, The ferric reducing ability of plasma (FRAP) as a measure of "antioxidant power": the FRAP assay, Analytical Biochemistry, 239 (1996) 70-76.

[74] A.V. Marques, H. Pereira, Lignin monomeric composition of corks from the barks of Betula pendula, Quercus suber and Quercus cerris determined by Py-GC-MS/FID, Journal of Analytical and Applied Pyrolysis, 100 (2013) 88-94.

[75] O. Faix, D. Meier, I. Fortmann, Thermal degradation products of wood, Holz als Roh-und Werkstoff, 48 (1990) 281-285. 
[76] J. Ralph, R.D. Hatfield, Pyrolysis-GC-MS characterization of forage materials, J. Agric. Food. Chem., 39 (1991) 1426-1437.

[77] A. Crivellaro, F.H. Schweingruber, Atlas of wood, bark and pith anatomy of Eastern Mediterranean trees and shrubs: with a special focus on Cyprus, Springer Science \& Business Media2013.

[78] F.H. Schweingruber, P. Steiger, A. Börner, Bark Anatomy of Trees and Shrubs in the Temperate Northern Hemisphere, Springer2019.

[79] E.T. Howard, Bark structure of southern upland oaks, Wood and Fiber Science, 9 (1977) 172-183.

[80] E. Nunes, T. Quilhó, H. Pereira, Anatomy and chemical composition of Pinus pinaster bark, IAWA Journal, 17 (1996) 141-150.

[81] E. Nunes, T. Quilhó, H. Pereira, Anatomy and chemical composition of Pinus pinea L. bark, Annals of Forest Science, 56 (1999) 479-484.

[82] M. Trockenbrodt, Qualitative structural changes during bark development in Quercus robur, Ulmus glabra, Populus tremula and Betula pendula, IAWA Journal, 12 (1991) 5-22.

[83] T. Whitmore, Studies in systematic bark morphology: IV. The bark of beech, oak and sweet chestnut, New Phytologist, 62 (1963) 161-169.

[84] A.U. Şen, T. Quilho, H. Pereira, Bark anatomy of Quercus cerris L. var. cerris from Turkey, Turkish Journal of Botany, 35 (2011) 45-55.

[85] T. Quilho, V. Sousa, F. Tavares, H. Pereira, Bark anatomy and cell size variation in Quercus faginea, Turkish Journal of Botany, 37 (2013).

[86] J. Gričar, Š. Jagodic, P. Prislan, Structure and subsequent seasonal changes in the bark of sessile oak (Quercus petraea), Trees, 29 (2015) 747-757.

[87] J. Oktaee, T. Lautenschläger, M. Günther, C. Neinhuis, A. Wagenführ, M. Lindner, A. Winkler, Characterization of willow bast fibers (Salix spp.) from short-rotation plantation as potential reinforcement for polymer composites, BioResources, 12 (2017) 4270-4282.

[88] M.C.N. Yemele, A. Koubaa, A. Cloutier, P. Soulounganga, M. Wolcott, Effect of bark fiber content and size on the mechanical properties of bark/HDPE composites, Composites Part A: Applied Science and Manufacturing, 41 (2010) 131-137.

[89] L. Sillero, R. Prado, M.A. Andrés, J. Labidi, Characterisation of bark of six species from mixed Atlantic forest, Industrial Crops and Products, 137 (2019) 276-284.

[90] J. Harun, P. Labosky, Chemical constituents of five northeastern barks, Wood and Fiber science, 17 (2007) 274-280.

[91] H. Kofujita, K. Ettyu, M. Ota, Characterization of the major components in bark from five Japanese tree species for chemical utilization, Wood Science and Technology, 33 (1999) 223-228.

[92] J. Dou, L. Galvis, U. Holopainen-Mantila, M. Reza, T. Tamminen, T. Vuorinen, Morphology and overall chemical characterization of willow (Salix sp.) inner bark and wood: toward controlled deconstruction of willow biomass, ACS Sustainable Chemistry \& Engineering, 4 (2016) 3871-3876.

[93] S.-Y. Yoon, B.-R. Kim, S.-H. Han, S.-J. Shin, Different response between woody core and bark of goat willow (Salix caprea L.) to concentrated phosphoric acid pretreatment followed by enzymatic saccharification, Energy, 81 (2015) 21-26.

[94] R.W. Bryers, Fireside slagging, fouling, and high-temperature corrosion of heat-transfer surface due to impurities in steam-raising fuels, Progress in Energy and Combustion Science, 22 (1996) 29-120.

[95] H. Pereira, I. Miranda, F. Tavares, T. Quilhó, J. Graça, J. Rodrigues, A. Shatalov, S. Knapic, Qualidade e utilização tecnológica do eucalipto (Eucalyptus globulus), Centro de Estudos Florestais, Lisbon, Portugal, 2011.

[96] H. Pereira, Variability of the chemical composition of cork, BioResources, 8 (2013) 2246-2256.

[97] G. Kain, B. Lienbacher, M.-C. Barbu, K. Richter, A. Petutschnigg, Larch (Larix decidua) bark insulation board: interactions of particle orientation, physical-mechanical and thermal properties, European Journal of Wood and Wood Products, 76 (2018) 489-498. 
[98] E. Maekawa, T. Ichizawa, T. Koshijima, An Evaluation of the Acid-Soluble Lignin Determination in Analyses of Lignin by the Sulfuric Acid Method, Journal of Wood Chemistry and Technology, 9 (1989) 549567.

[99] A. Lourenço, H. Pereira, Compositional Variability of Lignin in Biomass, in: M. Poletto (Ed.) LigninTrends and Applications, InTech2017, pp. 65-98.

[100] R.B. Santos, E.A. Capanema, M.Y. Balakshin, H.-m. Chang, H. Jameel, Lignin structural variation in hardwood species, J. Agric. Food. Chem., 60 (2012) 4923-4930.

[101] J. Dou, H. Kim, Y. Li, D. Padmakshan, F. Yue, J. Ralph, T. Vuorinen, Structural Characterization of Lignins from Willow Bark and Wood, J. Agric. Food. Chem., 66 (2018) 7294-7300.

[102] J. Ralph, C. Lapierre, W. Boerjan, Lignin structure and its engineering, Curr. Opin. Biotechnol., 56 (2019) 240-249.

[103] H. Kawamoto, Lignin pyrolysis reactions, J. Wood Sci., 63 (2017) 117-132.

[104] J. Rencoret, D. Neiva, G. Marques, A. Gutiérrez, H. Kim, J. Gominho, H. Pereira, J. Ralph, C. José, Hydroxystilbene glucosides are incorporated into Norway spruce bark lignin, Plant physiology, 180 (2019) 1310-1321.

[105] Y. Mottiar, R. Vanholme, W. Boerjan, J. Ralph, S.D. Mansfield, Designer lignins: harnessing the plasticity of lignification, Curr. Opin. Biotechnol., 37 (2016) 190-200.

[106] S. Van den Bosch, W. Schutyser, R. Vanholme, T. Driessen, S.F. Koelewijn, T. Renders, B. De Meester, W.J.J. Huijgen, W. Dehaen, C.M. Courtin, B. Lagrain, W. Boerjan, B.F. Sels, Reductive lignocellulose fractionation into soluble lignin-derived phenolic monomers and dimers and processable carbohydrate pulps, Energy \& Environmental Science, 8 (2015) 1748-1763.

[107] P.A. Ramos, C. Moreirinha, S.A. Santos, A. Almeida, C.S. Freire, A.M. Silva, A.J. Silvestre, Valorisation of bark lipophilic fractions from three Portuguese Salix species: A systematic study of the chemical composition and inhibitory activity on Escherichia coli, Industrial Crops and Products, 132 (2019) 245-252. [108] R.K. Devappa, S.K. Rakshit, R.F. Dekker, Potential of poplar bark phytochemicals as value-added coproducts from the wood and cellulosic bioethanol industry, BioEnergy Research, 8 (2015) 1235-1251.

[109] J.P. Ferreira, I. Miranda, V.B. Sousa, H. Pereira, Chemical composition of barks from Quercus faginea trees and characterization of their lipophilic and polar extracts, PLOS ONE, 13 (2018) e0197135.

[110] S. Willför, M. Ali, M. Karonen, M. Reunanen, M. Arfan, R. Harlamow, Extractives in bark of different conifer species growing in Pakistan, Holzforschung, 63 (2009) 551-558.

[111] H. Hafizoğlu, B. Holmbom, M. Reunanen, Chemical composition of lipophilic and phenolic constituents of barks from Pinus nigra, Abies bornmülleriana and Castanea sativa, Holzforschung, 56 (2002) 257-260.

[112] J.C. Menezes, N. Edraki, S.P. Kamat, M. Khoshneviszadeh, Z. Kayani, H.H. Mirzaei, R. Miri, N. Erfani, M. Nejati, J.A. Cavaleiro, Long chain alkyl esters of hydroxycinnamic acids as promising anticancer agents: selective induction of apoptosis in cancer cells, J. Agric. Food. Chem., 65 (2017) 7228-7239.

[113] C. Freire, A. Silvestre, C.P. Neto, J. Cavaleiro, Lipophilic extractives of the inner and outer barks of Eucalyptus globulus, Holzforschung, 56 (2002) 372-379.

[114] J. Gominho, R.A. Costa, A. Lourenço, T. Quilhó, H. Pereira, Eucalyptus globulus Stumps Bark: Chemical and Anatomical Characterization Under a Valorisation Perspective, Waste and Biomass Valorization, (2020) 1-13.

[115] M. König, E. Scholz, R. Hartmann, W. Lehmann, H. Rimpler, Ellagitannins and complex tannins from Quercus petraea bark, Journal of Natural Products, 57 (1994) 1411-1415.

[116] S. Bianchi, I. Kroslakova, R. Janzon, I. Mayer, B. Saake, F. Pichelin, Characterization of condensed tannins and carbohydrates in hot water bark extracts of European softwood species, Phytochemistry, 120 (2015) 53-61. 
[117] Â. Luís, N. Gil, M. Amaral, A. Duarte, Antioxidant activities of extracts from Acacia melanoxylon, Acacia dealbata and Olea europaea and alkaloids estimation, International Journal of Pharmacy and Pharmaceutical Sciences, 4 (2012) 225-231.

[118] A. Johansson, By-product recovery and valorisation in the kraft industry: A review of current trends in the recovery and use of turpentine and tall oil derivatives, Biomass, 2 (1982) 103-113.

[119] A. Scalbert, Antimicrobial properties of tannins, Phytochemistry, 30 (1991) 3875-3883. 